\title{
NERVE GROWTH FACTOR-INDUCED DIFFERENTIATION OF PC12 CELLS: EVALUATION OF CHANGES IN RNA AND DNA METABOLISM $^{1}$
}

\author{
PETER W. GUNNING, ${ }^{2}$ GARY E. LANDRETH, PAUL LAYER,${ }^{3}$ MICHAEL IGNATIUS AND \\ ERIC M. SHOOTER
}

Department of Neurobiology, Stanford University School of Medicine, Stanford, California 94305

\begin{abstract}
The relationship between both DNA and RNA metabolism and the nerve growth factor ( $\beta$ NGF)induced differentiation of PC12 cells was investigated. Cells remained in log phase growth for 4 days after exposure to $\beta \mathrm{NGF}$. DNA synthesis was similarly unaffected by $\beta$ NGF during this time. Thereafter, a gradual decrease in DNA synthesis was observed. In contrast, as many as $40 \%$ of the cells display neurites after 4 days exposure to $\beta \mathrm{NGF}$. The implication, that cells which have begun to differentiate morphologically may still synthesize DNA, was confirmed using autoradiography. The cellular RNA concentration was elevated significantly within 1 day of exposure to $\beta N G F$ and continued to increase for up to 6 days. Dose-response analysis revealed that this increase in cellular RNA, both rRNA and tRNA, closely correlates with the size and number of neurites per cell rather than with the cell's capacity to grow a neurite per se. A parallel rise in the cellular protein concentration was observed also. It was concluded, therefore, that (1) cessation of cell division is not a prerequisite for the initiation of the morphological differentiation of these cells and (2) the elevation of the cellular RNA content influences some quantitative aspects of neurite outgrowth.
\end{abstract}

When the pheochromocytoma cell line PC12 is exposed to nerve growth factor (NGF), the cells respond over a period of a week by ceasing cell division and extending neurites (Greene and Tischler, 1976). This is accompanied by the induction of electrical excitability, sensitivity to acetylcholine, and an increase in the specific activity of choline acetyltransferase (Dichter et al., 1977; Schubert et al., 1977). Since these cells grow indefinitely in the absence of NGF, it is possible to identify biochemical changes which are induced specifically by NGF and which may direct this differentiation.

A number of biochemical changes have been observed during this induction process. These include an elevation in ornithine decarboxylase activity (Hatanaka et al., 1978), increased synthesis of a number of proteins (Garrels and Schubert, 1979; McGuire et al., 1978), and in-

\footnotetext{
${ }^{1}$ We wish to thank Dr. Mark A. Bothwell for helpful discussions. This work was supported by grants from the National Institute of Neurological and Communicative Diseases and Stroke (NS 04270) and the American Cancer Society (BC 325). P. W. G. was supported by a California Division-American Cancer Society Junior Fellowship No. J466, G. E. L. by a National Institutes of Health Fellowship, and P. L. by a Fellowship from the Deutscheforschungsgemeinschaft.

Present address: Department of Medicine, Veterans Administration Hospital, Palo Alto, CA 94304.

${ }^{3}$ Present address: Max-Planck Institut für Virusforschung, Spemann Strasse 35, 74 Tubingen, West Germany.
}

creased amino acid uptake (McGuire and Greene, 1979). Whether any of these events are either necessary or involved directly in the morphogenesis of the PC12 cell has not been demonstrated yet.

Recently, it has been shown that the PC12 cells internalize NGF and that a significant fraction of the NGF becomes associated with the nucleus (Yankner and Shooter, 1979). Since the inner nuclear membrane of these cells have specific receptors for NGF (Yankner and Shooter, 1979), it appears likely that the nucleus may be a key site in the mediation of NGF action. This is supported by the data of Burstein and Greene (1978) which implicate a transcription-dependent step in the morphogenesis of these cells.

We have sought, therefore, to identify changes in nuclear metabolism which are involved in this NGF-induced morphogenesis. In particular, we have examined the relationship of DNA and RNA synthesis to the initiation and subsequent growth of neurites from these cells.

\section{Materials and Methods}

Cell growth and induction conditions. The $\mathrm{PC} 12$ clone of a rat pheochromocytoma was obtained from David Schubert. The cells were grown in Dulbecco's modified Eagle's medium (GIBCO) containing $10 \%$ fetal calf serum and $5 \%$ horse serum on polystyrene tissue culture dishes 
(NUNC). Cultures were maintained in a water-saturated atmosphere of $88 \%$ air, $12 \% \mathrm{CO}_{2}$. Inductions were performed by replating subconfluent cells at a density of 1 to $2 \times 10^{4} / \mathrm{cm}^{2}$. The cells were allowed to reach log phase growth (2 days). At that time, fresh medium was added together with $\beta$ NGF (prepared by the method of Smith et al., 1968) at the concentrations indicated. Unless otherwise noted, fresh medium and $\beta$ NGF were added every 2 days.

The experiments were performed using tissue culture plastic as a substratum since the cells used were adapted to plastic by Dr. David Schubert and have been maintained in this laboratory for 3 years using this procedure. No problems, such as cell death or cell detachment, have been observed. Furthermore, the number of plates used in these experiments precluded the routine coating of the plates with collagen.

Quantitation of neurite outgrowth. The morphological differentiation of these cells was assayed by determining the percentage of cells which were neurite bearing. The cells were viewed using a Leitz Diavert microscope equipped with phase contrast optics. A neurite was defined as a process extending from the cell over one cell body diameter in length and displaying a growth cone at its tip. The neurites scored displayed the characteristic microspikes around the growth cones, and using timelapse cinematography, we have shown subsequently a continuous growth of these neurites. Although protoplasmic extrusions from these cells were observed, they were particularly small (less than one-quarter of a cell body diameter) and displayed no growth-cone-like properties. In contrast to this behavior on a tissue culture plastic substratum, protoplasmic extrusions are considerably more prominent when the cells are grown on a collagen-coated surface. At least 600 cells were examined in randomly chosen fields on each plate. As the inductions proceed, the cells often form large clumps, particularly after 6 to 7 days exposure to $\beta$ NGF. In such situations, only cells at the perimeter of the clump could be assayed. In some experiments, a neurite growth index (NGI) was estimated using a protocol similar to that of Mizel and Bamburg (1976). The cells were scored using a single blind procedure. The number of neurites per cell and the relative neurite lengths each were graded on a scale of 0 to 4 . The NGI was taken as the average sum of both per cell.

$D N A, R N A$, and protein determinations. The cells were dislodged mechanically from the dishes by trituration and collected by centrifugation at $750 \times \mathrm{g}_{\mathrm{av}}$ for 5 min. Acid-soluble material was obtained by extracting the cell pellet three times with $0.5 \mathrm{M}$ perchloric acid (PCA) at $4^{\circ} \mathrm{C}$. The acid-insoluble material was suspended in $1 \mathrm{M} \mathrm{NaOH}$ and incubated at $37^{\circ} \mathrm{C}$ for $18 \mathrm{hr}$. A sample of the solution was taken for protein determination by the method of Lowry et al. (1951), using bovine serum albumin (BSA; Sigma) as a standard. Concentrated PCA was added to the remainder of the solution to a final concentration of $0.5 \mathrm{M}$ PCA and left at $4^{\circ} \mathrm{C}$ for $1 \mathrm{hr}$. The resulting precipitate was collected at $10,000 \times g_{\text {av }}$ for 10 min and washed once with $0.5 \mathrm{M}$ PCA. The two supernatants were combined for RNA determination. The pellet was extracted twice with $0.5 \mathrm{M} \mathrm{PCA}$ at $80^{\circ} \mathrm{C}$ for 30 min and the combined supernatants were taken for DNA determination. RNA and DNA were determined by the two-wavelength method of Tsanev and Markov (1960). The amount of DNA was taken as a measurement of cell number with $1 \times 10^{6} \log$ phase cells containing $10 \mu \mathrm{g}$ of DNA. The content of DNA per cell was shown to be unchanged by prolonged exposure to $\beta N G F$ using flow microfluorimetry. Thus, the measurement of total DNA can be equated directly with cell number in all of these experiments. The ratios of RNA:DNA and protein:DNA were taken as a measure of the cellular RNA and protein concentrations. Approximately 95\% of PC12 RNA is accounted for by rRNA and tRNA.

$D N A$ and $R N A$ synthesis. DNA synthesis was assayed by adding $\left[\right.$ methyl $\left.{ }^{3} \mathrm{H}\right]$ thymidine $(85 \mathrm{Ci} / \mathrm{mmol}$, Amersham) to the medium at a final concentration of $0.5 \mu \mathrm{Ci}$ / $\mathrm{ml}$. After a $1-\mathrm{hr}$ incubation at $37^{\circ} \mathrm{C}$, the medium was removed and the dishes were washed three times with ice cold Dulbecco's phosphate-buffered saline (PBS) containing $1 \mathrm{~mm}$ thymidine. The cells then were dislodged mechanically and collected by centrifugation. The cells were extracted as described above and an aliquot of the DNA hydrolysate was counted in a Beckman LS-250 scintillation counter using a Triton cocktail (33\% Triton $\mathrm{X}-100,67 \%$ toluene, $0.1 \mathrm{gm} /$ liter of 1,4-bis-2-(5-phenyloxazolyl)benzene (POPOP) and $5 \mathrm{gm} /$ liter of 2,5-diphenyloxazole (PPO)). DNA synthesis was measured as counts per min of thymidine incorporated per $\mu \mathrm{g}$ of DNA. In all cases, over $90 \%$ of the $\left[{ }^{3} \mathrm{H}\right]$ thymidine taken up by the cells was incorporated into DNA. This reflects a very small intracellular pool of thymidine and indicates that thymidine uptake in these cells is coupled tightly to ongoing DNA synthesis.

RNA synthesis was assayed exactly as described for DNA synthesis using $\left[5-{ }^{3} \mathrm{H}\right]$ uridine $(27 \mathrm{Ci} / \mathrm{mmol}$, Amersham) and substituting $1 \mathrm{~mm}$ uridine for thymidine. RNA synthesis was measured as counts per min of uridine incorporated per $\mu \mathrm{g}$ of DNA. The uptake of uridine was determined also by counting an aliquot of the acid-soluble extract and was expressed as uptake per $\mu \mathrm{g}$ of DNA.

$R N A$ purification. RNA was purified from the cells and analyzed by polyacrylamide gel electrophoresis as described previously (Gunning et al., 1979). The gels were scanned at $265 \mathrm{~nm}$ using a Gilford 2000 spectrophotometer equipped with a linear transport accessory. The relative amounts of individual RNA species were determined by cutting out the corresponding gel scan peaks and weighing them (Gunning et al., 1979).

Determination of $N G F$ concentration. $\beta N G F$ was radioiodinated according to the method of Sutter et al. (1979). A trace amount of ${ }^{125} \mathrm{I}-\beta \mathrm{NGF}$ was added to the stock of $\beta \mathrm{NGF}$ solution prior to addition to the cell medium. At indicated times, aliquots of the medium were taken and an equal volume of $20 \%(\mathrm{w} / \mathrm{v})$ trichloroacetic acid was added to some. These samples were allowed to stand at $4^{\circ} \mathrm{C}$ for over $12 \mathrm{hr}$. Acid-precipitable material was collected by centrifugation and the fraction of acidprecipitable ${ }^{125} \mathrm{I}-\beta \mathrm{NGF}$ was determined by counting the pellet and a sample of the medium in a Beckman Gamma 300 counter. Incubation of ${ }^{125} \mathrm{I}-\beta \mathrm{NGF}$ at $37^{\circ} \mathrm{C}$ in medium alone did not decrease acid precipitability over a period of 6 days. 'The ${ }^{125} \mathrm{I}-\beta \mathrm{NGF}$ used in these experiments was 
$92 \pm 1 \%$ acid precipitable. With prolonged exposure to the cells, precipitability decreased to a plateau value, usually about $20 \%$, which was found by bioassay and immunoprecipitability to be equivalent to zero biological activity of NGF (P. Layer and E. M. Shooter, manuscript in preparation). The concentration of $\beta \mathrm{NGF}$ was calculated using the equation:

$$
[\beta \mathrm{NGF}]=A \times \frac{B-C}{92-C}
$$

where $A$ is the concentration of $\beta$ NGF initially added, $B$ is the percentage of precipitability in the aliquot, and $C$ is the plateau value percentage of precipitability corresponding to zero biological activity. Each value obtained is the result of duplicate determinations upon each of duplicate sister cultures. Variations among sister cultures was less than $5 \%$ of the mean.

An aliquot of the medium also was assayed for the level of $\beta$ NGF using the PC12 bioassay (Greene, 1977). In all experiments, the $\beta \mathrm{NGF}$ concentration determined by this method was lower than that obtained using ${ }^{125} \mathrm{I}$ $\beta$ NGF. This was complicated, however, by the finding of inhibitory material in the cell medium. The nature of this material is unknown, but its level does appear to be a function of exposure of the cells to $\beta \mathrm{NGF}$ over a prolonged period. Wc, therefore, only present $\beta \mathrm{NGF}$ concentrations determined by the ${ }^{125} \mathrm{I}-\beta \mathrm{NGF}$ method.

Autoradiography. PC12 cells were plated onto polylysine-coated glass coverslips (Letourneau, 1975) contained within tissue culture dishes. The induction was performed as described above. After 5 days exposure to
$50 \mathrm{ng} / \mathrm{ml}$ of $\beta \mathrm{NGF}$, [methyl- $\left.{ }^{3} \mathrm{H}\right]$ thymidine was added to the medium at a final concentration of $2 \mu \mathrm{Ci} / \mathrm{ml}$ and $2 \mathrm{hr}$ later, the medium was withdrawn. The dish was washed three times with phosphate-buffered saline containing 1 $\mathrm{mm}$ thymidine at $4^{\circ} \mathrm{C}$ for $1 \mathrm{~min}$. The cells were fixed with $1 \%$ paraformaldehyde plus $2 \%$ glutaraldehyde in $5 \%$ sucrose for $20 \mathrm{~min}$. They were washed three times with 0.1 M phosphate buffer (pH 7.4) and twice with distilled water. Autoradiograph procedures were essentially those described by Kopriwa and Leblond (1962). Kodak NTB2 nuclear track emulsion was diluted 1:1 with distilled water at $37^{\circ} \mathrm{C}$. Coverslips were dipped for $3 \mathrm{sec}$ and allowed to set at $20^{\circ} \mathrm{C}$ for $15 \mathrm{~min}$. The coverslips were stored overnight in light-tight boxes at $20^{\circ} \mathrm{C}$ and Drierite was added on the following morning. Coverslips then were left to expose at $4^{\circ} \mathrm{C}$ for 14 days. The exposed coverslips were developed in Kodak D-19 developer for $2 \mathrm{~min}$ at $21^{\circ} \mathrm{C}$, washed for $15 \mathrm{sec}$ in distilled water, fixed in Kodak fixer for $2 \mathrm{~min}$, and washed with filtered distilled water for 15 min. The air-dried coverslips then were mounted on glass slides with a 1:1 dilution of glycerine in $\mathrm{H}_{2} \mathrm{O}$ and viewed with standard phase optics at $\times 40$.

The following controls were performed. It was shown that over $98 \%$ of the acid-precipitable ${ }^{3} \mathrm{H}$ counts per min present in the cells after a 2 -hr exposure to $\left[{ }^{3} \mathrm{H}\right]$ thymidine was in the form of DNA. Furthermore, it was shown that concurrent exposure of cells to $\left[{ }^{3} \mathrm{H}\right]$ thymidine and $1 \mu \mathbf{M}$ cytosine arabinoside for $2 \mathrm{hr}$ resulted in no nuclear incorporation when assayed by autoradiography. This rules out any "false incorporation" due to mechanical deformation of the emulsion.

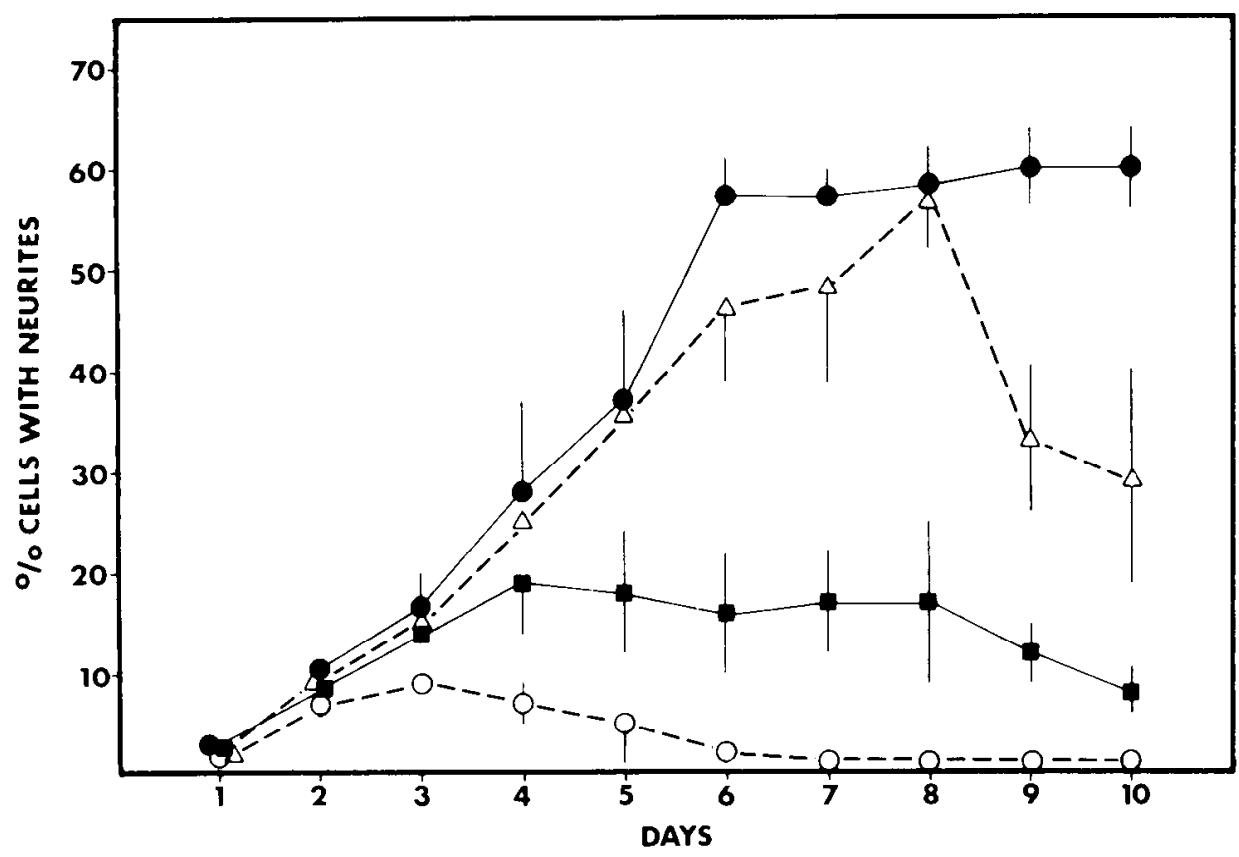

Figure 1. Induction of neurite outgrowth from PC12 cells. Subconfluent cells were replated and, after 2 days, $\beta$ NGF and fresh medium were added. Fresh $\beta N G F$ and medium then were added every 2 days. The $\beta$ NGF concentrations used, in nanograms per $\mathrm{ml}$, are $5\left(\mathrm{O}_{-}-\cup\right), 25(\square), 50(\triangle--\triangle)$, and $150(\square)$. The values shown are the mean of at least six independent experiments and the vertical bar represents the standard deviation. Sister cultures which received no $\beta N G F$ displayed no neurite outgrowth at any time. 


\section{Results}

Characterization of PC12 cell induction. When PC12 cells are exposed to high concentrations of $\beta \mathrm{NGF}$, a progressive increase in the fraction of neurite-bearing cells is observed (Fig. 1). Maximum induction occurs after 6 to 8 days and corresponds to about $60 \%$ of the cells having responded morphologically. The induction of neurite outgrowth is a function of the $\beta$ NGF concentration but dose responsiveness of the morphological differentiation varies throughout the induction time course. In particular, with increasing time of exposure to $\beta \mathrm{NGF}$, progressively higher concentrations are required to attain maximal induction (Fig. 1). Increasing the $\beta \mathrm{NGF}$ concentration beyond $150 \mathrm{ng} / \mathrm{ml}$ gave no further improvement in the cell response.
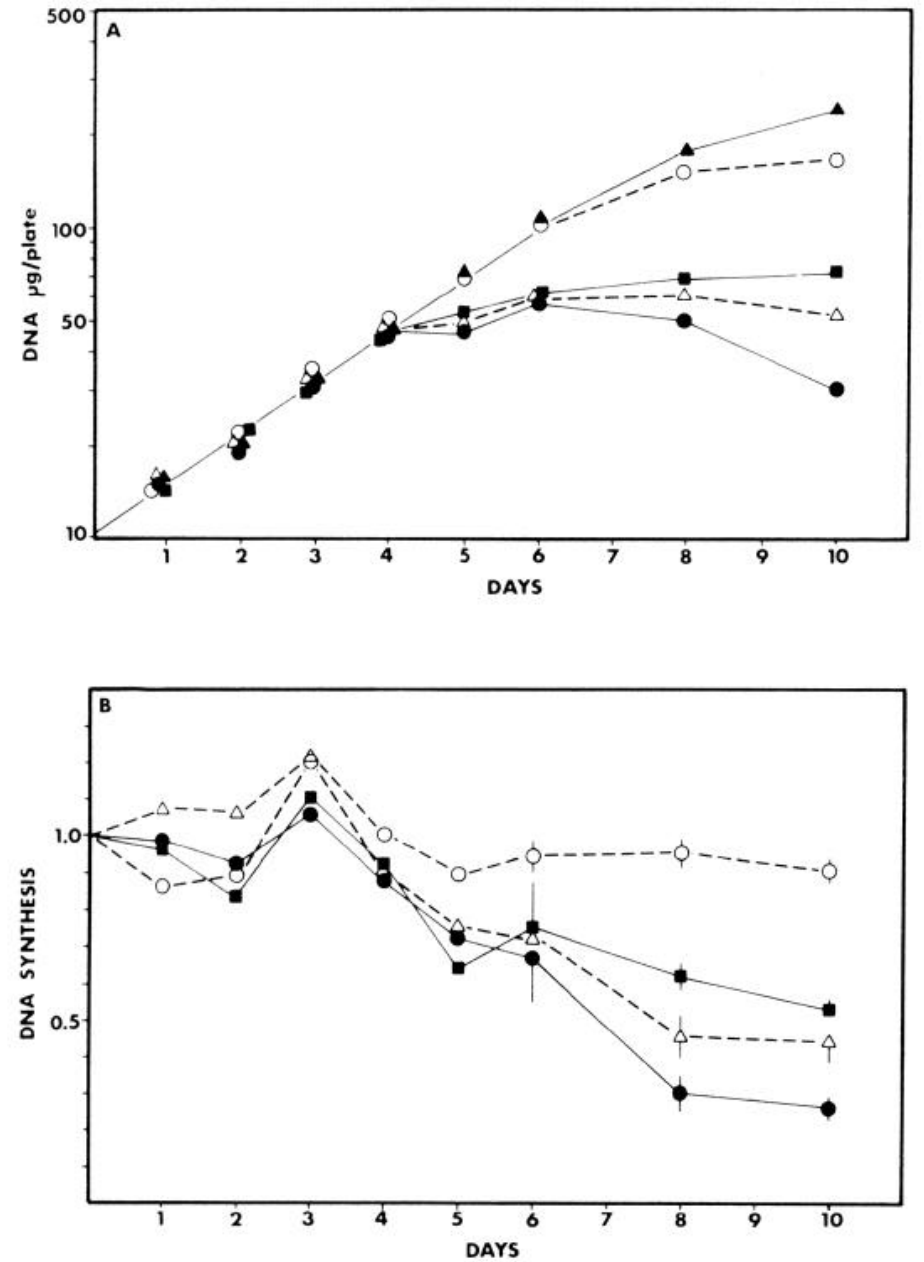

Figure 2. Cell division and DNA synthesis during $\mathrm{PC} 12$ differentiation. Cells were treated exactly as described in Figure 1. On each day, duplicate plates were assayed for $(A)$ total DNA and $(B)$ DNA synthesis. The total DNA values shown are the result of a typical experiment. The DNA synthesis values are expressed as a ratio relative to control sister cultures. The DNA synthesis results are the means of four independent experiments and a bar, representing the $\mathrm{SD}$, is shown where differences between different $\beta \mathrm{NGF}$ concentrations are observed. The $\beta$ NGF concentrations used, in nanograms per $\mathrm{ml}$, are 0 $(\boldsymbol{\Delta}-\mathbf{\Delta}), 5\left(\mathrm{O}_{-} \mathrm{-}\right), 25(\mathbf{\square}), 50(\Delta---\Delta)$, and 150 (-)
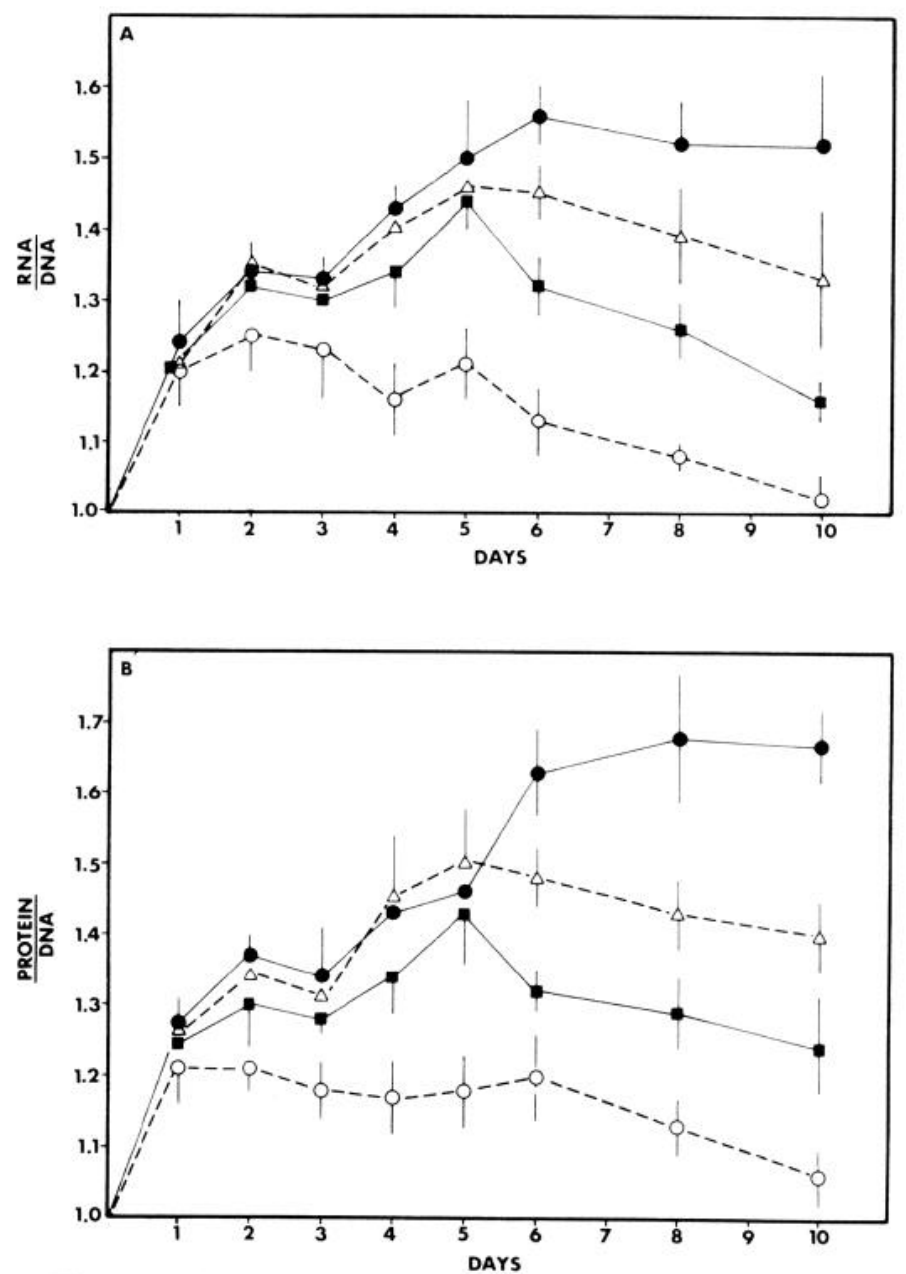

Figure 3. Cellular RNA and protein concentrations during $\mathrm{PC} 12$ differentiation. Cells were treated exactly as described in Figure 1. On each day, duplicate plates were harvested and cellular RNA and protein concentrations were measured as $(A)$ RNA/DNA and $(B)$ protein/DNA, respectively. The values are expressed as a ratio relative to control sister cultures and are the mean of at least six independent experiments. The bar represents the SD. The $\beta \mathrm{NGF}$ concentrations used, in nanograms per $\mathrm{ml}$ are $5\left(\bigcirc_{-}-\mathrm{O}\right), 25(\square \square), 50(\triangle---\triangle)$, and $150(-)$.

In all individual experiment $\$$, two distinct phases of neurite outgrowth were apparent. An initial slow rise in the fraction of responding cells until day 3,4 , or 5 then was followed by a rapid increase over the succeeding few days. The precise timing of this increase varied from experiment to experiment and this resulted in a large scatter among the data points at days 4 and 5 (Fig. 1). Examples of this biphasic neurite outgrowth are presented below.

The cells continue log phase growth for at least 4 days following the initial addition of $\beta$ NGF (Fig. $2 A$ ). Thereafter, the cell number appears to reach a plateau and, in some cases, actually decreases. Thus, by day 4 , where up to $30 \%$ of the cells possess neurites, the cells are maintaining log phase growth. It should be noted that the plateau may be misleading because cell death and lifting off the dish into the medium is pronounced toward the 
end of the first week. This both exaggerates the apparent approach to the zero growth plateau and explains the apparent decrease in cell number observed using high $\beta$ NGF levels.

Analysis of DNA synthesis is a much more reliable assay for the effect of $\beta \mathrm{NGF}$ upon cell division. No significant decrease in the level of DNA synthesis relative to control cells was detected prior to 5 days exposure to $\beta$ NGF (Fig. $2 B$ ). Thereafter, a progressive decrease was observed. Although this decline shows a clear dependency upon the amount of $\beta$ NGF present, it does not correlate well with the neurite outgrowth response at these later times (Fig. $2 B$; cf., Fig. 1). The data indicate that the capacity of $\beta \mathrm{NGF}$ to inhibit the division of $\mathrm{PC} 12$ cells is not related to the initiation of neurite outgrowth.

In contrast, the cellular concentration of RNA is increased significantly within $24 \mathrm{hr}$ of exposure to $\beta \mathrm{NGF}$ (Fig. $3 A$ ). At doses greater than $5 \mathrm{ng} / \mathrm{ml}$, a pronounced biphasicity is noted in the temporal properties of this RNA increase. Maximum elevation of the RNA concentration shows a progressive requirement for higher levels of $\beta \mathrm{NGF}$ with the passage of time. The relationships of the $\beta$ NGF concentrations used to neurite outgrowth and to RNA levels are very similar and both the first and second rises in cellular RNA levels precede or coincide with the two phases of neurite outgrowth (Fig. $3 A$; cf., Fig. 1).

The protein concentration of these cells rises in an almost identical manner to that of the RNA increase
(Fig. $3 B$ ). This, perhaps, is to be expected since a rise in cellular RNA, over $95 \%$ of which is comprised of rRNA and tRNA (not shown), would be expected to raise the protein synthetic capacity of these cells. The close relationship between the cellular RNA and protein levels is further illustrated by dose responsiveness of these increases following $24 \mathrm{hr}$. exposure to $\beta \mathrm{NGF}$ (Fig. 4). Greater than half-maximal increases in both are seen at a $\beta$ NGF concentration below $0.25 \mathrm{ng} / \mathrm{ml}$. This indicates a particularly high sensitivity of these two cellular parameters to $\beta \mathrm{NGF}$.

Dose responsiveness of induction. When $\beta$ NGF-induced PC12 cells are divested of their neurites by mechanical means and replated in the presence of $\beta \mathrm{NGF}$, they can regenerate neurites within $24 \mathrm{hr}$ (Greene, 1977). This response of the cells can be used as a convenient measure of the extent of $\beta \mathrm{NGF}$-induced differentiation. Optimal induction of PC12 differentiation after 6 days exposure to $\beta \mathrm{NGF}$ was attained at inducing concentrations of 50 to $100 \mathrm{ng} / \mathrm{ml}$ of $\beta \mathrm{NGF}$ (Fig. $5 A$ ). However, considerable differences exist in the relative neurite outgrowth at high inducing doses. When neurite length and number per cell are assessed in terms of a nerve growth index (NGI), optimal induction requires $250 \mathrm{ng} / \mathrm{ml}$ (Fig. $5 A)$. The half-maximal neurite regeneration and NGI is achieved at inducing concentrations of 10 and $25 \mathrm{ng} / \mathrm{ml}$, respectively.

Half-maximal elevation of the cellular RNA and protein levels occurs at $25 \mathrm{ng} / \mathrm{ml}$ and are maximal at 100

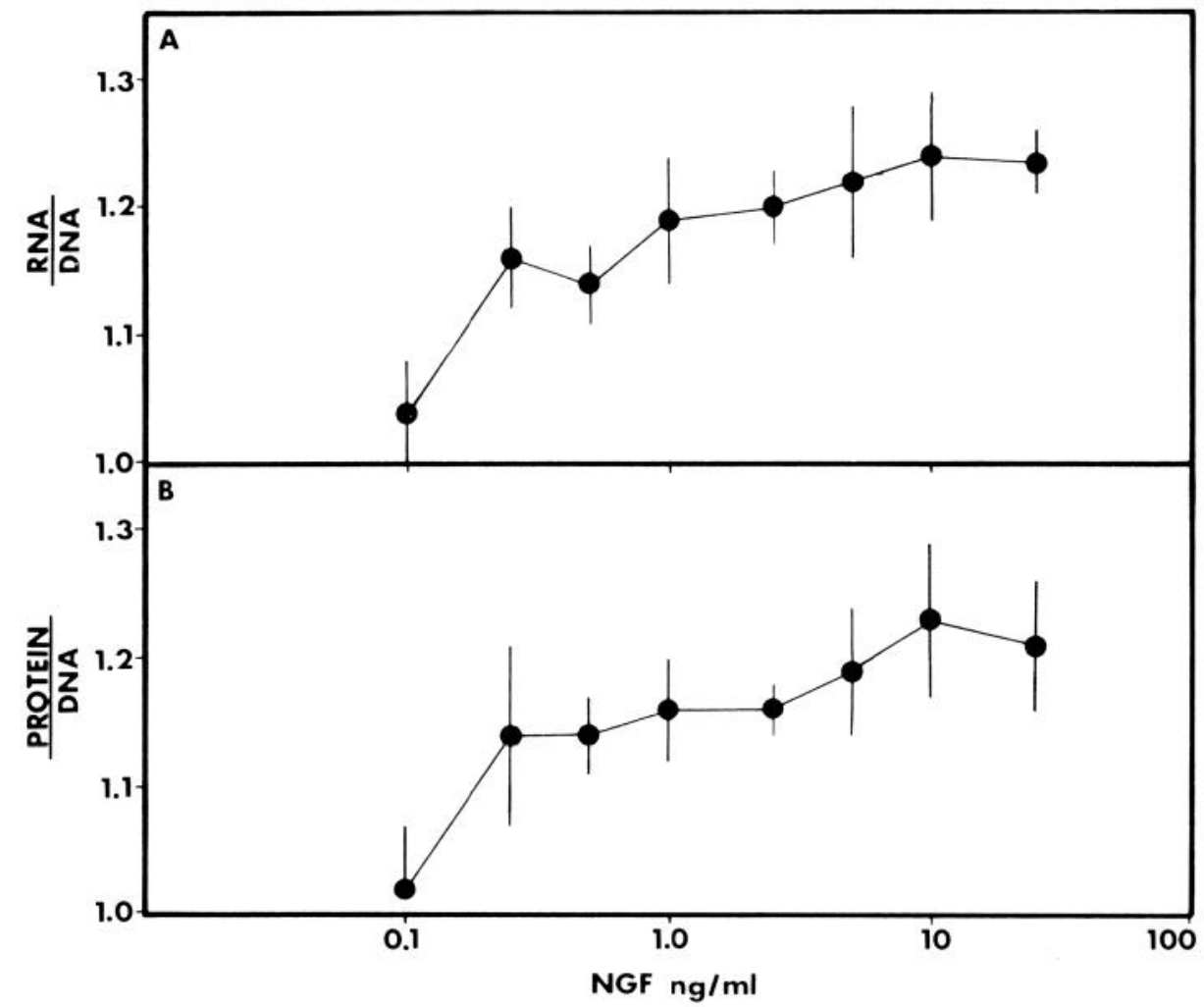

Figure 4. Cellular RNA and protein concentrations in PC12 cells after 24 hr exposure to $\beta$ NGF. Cells were treated exactly as described in Figure 1 and $\beta N G F$ was added at the range of concentrations shown. After $24 \mathrm{hr}$ exposure to $\beta \mathrm{NGF}$, the cells were harvested and cellular RNA and protein concentrations were measured as $(A)$ RNA/ DNA and $(B)$ protein/DNA relative to control sister cultures. The values are the means of four independent determinations and the bar shows the SD. 

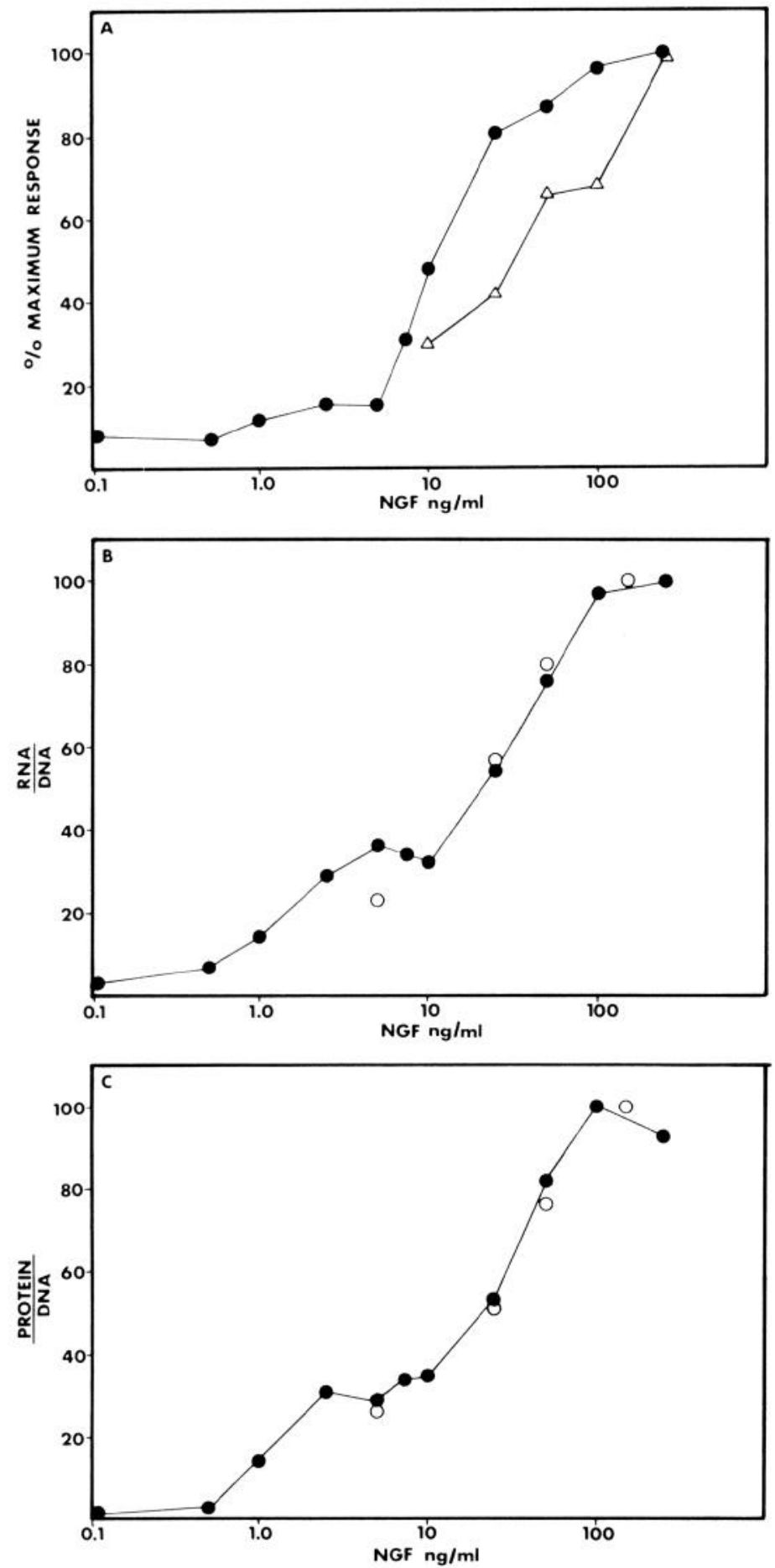

Figure 5. Dose-response characteristics of PC12 differentiation induced by $\beta \mathrm{NGF}$. Cells were treated exactly as described in Figure 1 and exposed to a range of $\beta \mathrm{NGF}$ concentrations for 6 days. The cells then were harvested and a fraction was replated under the bioassay conditions described by Greene (1977) using $1 \mathrm{ng} / \mathrm{ml}$ of $\beta \mathrm{NGF}$. After a further $24 \mathrm{hr}$, the fraction of cell clumps which had regenerated their neurites and the nerve growth index (NGI) for each sample were assayed. The remainder of the cells were assayed for RNA/DNA and protein/DNA and the values were expressed as a ratio relative to control sister cultures. The percentage of maximal response is shown for $(A)$ neurite regeneration

$\triangle-\triangle),(B)$ RNA/DNA, and $(C)$ protein/DNA. In $B$ and $C$, the 6 -day values shown in Figure 3 for $5,25,50$, and $150 \mathrm{ng} / \mathrm{ml}$ of $\beta \mathrm{NGF}$ also are shown as open circles. $\mathrm{ng} / \mathrm{ml}$ (Fig. 5, $B$ and $C$ ). The results indicate that these increases correlate more closely with the NGI than with the capacity to regenerate neurites per se. It is also clear that a close relationship exists between the rise in RNA and that in protein.

Analysis of the RNA from these samples revealed no significant differences between the relative amounts of $28 \mathrm{~S}, 18 \mathrm{~S}$, and $5 \mathrm{~S}$ rRNAs and $4 \mathrm{~S}$ tRNA (not shown). Together, these molecules account for over $95 \%$ of total PC12 cell RNA.

The dose responsiveness for half-maximal morphological differentiation (as judged by the ability of PC12 cells to regenerate neurites) is $10 \mathrm{ng} / \mathrm{ml}$ of $\beta N G F$ (Fig. $5 A$ ). In contrast, Greene (1978) found that half-maximal neurite induction, when performed in the absence of serum, is achieved at a $\beta \mathrm{NGF}$ concentration of $1 \mathrm{ng} / \mathrm{ml}$ and is maximal at $10 \mathrm{ng} / \mathrm{ml}$. Thus, the dose responsiveness appears to depend upon how the neurite induction is both performed and assayed.

In addition, the data on the dose response of neurite outgrowth, DNA synthesis, and RNA and protein levels imply that, as the induction progresses, increasingly higher concentrations of $\beta$ NGF are required to elicit the full biological response (Figs. 1 to 3 ). Since fresh $\beta$ NGF is added every 2 days in these experiments, it was necessary to check if the biological concentration of $\beta \mathrm{NGF}$ remained the same during each 2-day period.

$\beta N G F$ concentration during induction. Table I shows the concentration of $\beta \mathrm{NGF}$ remaining in the medium on each day of an 8-day induction time course. The concentration changes significantly in the 2 days following each fresh addition. Furthermore, the size of the decrease is a function of the time after the initial $\beta$ NGF addition. This, in turn, may be a function of the cell number on the dish since the cells undergo at least two cell divisions after the addition of $\beta$ NGF and, after 5 days, the cell number is at least 5 -fold greater than that initially present (Fig. 2A). Thus, one would expect that the doseresponse requirements of the biological effects during induction would show a progressive shift to higher concentrations of $\beta \mathrm{NGF}$ at later times. It is also clear that absolute interpretation of the dose-response analysis in this system and comparison with the results of others is difficult unless the $\beta$ NGF concentration is measured throughout the experiment.

TABLE I

$\beta N G F$ concentration during PC12 differentiation

Cells were treated exactly as described in Figure 1.

\begin{tabular}{llrrr}
\hline Day & \multicolumn{5}{c}{ Concentration in Medium } \\
\hline & 5 & 25 & 50 & 150 \\
$0^{a}$ & 4.2 & 22 & 47 & 139 \\
1 & 2.4 & 19 & 38 & 125 \\
$2^{a}$ & 1.9 & 15 & 36 & 111 \\
3 & 0.4 & 8 & 19 & 81 \\
$4^{a}$ & 1.0 & 10 & 29 & 94 \\
5 & 0 & 0 & 4 & 39 \\
$6^{a}$ & 0.9 & 11 & 27 & 95 \\
7 & 0 & 0 & 3 & 39 \\
8 & 0 & 0 & & \\
\hline
\end{tabular}

${ }^{a}$ On days $0,2,4$, and 6 , the $\beta$ NGF concentration was determined and then the medium was replaced with fresh medium and $\beta \mathrm{NGF}$ at concentrations of $5,25,50$, or $150 \mathrm{ng} / \mathrm{ml}$. 
Inhibition of PC12 induction by fresh serum addition. The induction of neurite outgrowth in medium containing serum usually displays pronounced biphasicity. This is seen clearly in Figure 6 where a considerable increase in the induction rate is seen between days 3 and 5 compared with the initial 3 days. When the induction is performed on sister cultures in medium containing BSA only, a steady monophasic increase is seen for up to 7 days when a more pronounced induction is also observed (Fig. 6). This indicates that the addition of fresh serum every 2 days, in contrast to BSA, markedly reduces the rate and final extent of induction. It should be noted also that the biphasicity is not a function of changing the medium every 2 days per se (Fig. 6 ).

The effect was investigated further. An induction was started with the addition of fresh serum and $\beta$ NGF. Some dishes received no further addition, others were supplemented with fresh $\beta$ NGF every 2 days, and the remainder were induced with changes of medium plus serum and $\beta$ NGF every 2 days. Again, clear biphasicity in the neurite outgrowth response was detected with the standard induction (Fig. 7A). Multiple supplements of $\beta$ NGF, with no serum changes, resulted in a primarily monophasic response and neurite outgrowth from 70 to $80 \%$ of the cells after 6 days (Fig. $7 B$ ). A similar monophasic response also was observed with only one addition of $\beta \mathrm{NGF}$ (Fig. $7 C$ ). However, in this case, neurite outgrowth decreased 4 days after a single addition of 25 or $50 \mathrm{ng} / \mathrm{ml}$ of $\beta \mathrm{NGF}$ (Fig. $7 C$ ) and after 6 days using 150 $\mathrm{ng} / \mathrm{ml}$ (not shown). Thus, when fresh serum is not added every 2 days, neurite outgrowth is monophasic and more rapid, and a larger fraction of the cells finally responds.

The concentration of $\beta \mathrm{NGF}$ was measured at each day of the inductions. In the case of multiple $\beta$ NGF supplementation, cells receiving $5 \mathrm{ng} / \mathrm{ml}$ additions first show a submaximal morphological response at day 4 (Fig. $7 B$ ). This occurs at a time when the concentration of $\beta \mathrm{NGF}$ drops from 2.9 to $0.6 \mathrm{ng} / \mathrm{ml}$ (Table II). Cells which receive only one addition of $5 \mathrm{ng} / \mathrm{ml}$ first show a submaximal response at day 3 (Fig. $7 C$ ). This coincides with a drop in the $\beta \mathrm{NGF}$ concentration from 2.1 to $1.5 \mathrm{ng} / \mathrm{ml}$ (Table III). Furthermore, a single addition of 25 or $50 \mathrm{ng} / \mathrm{ml}$ results in a decrease below the maximal response at day 5 (Fig. $7 C$ ). It is at this time that the $\beta \mathrm{NGF}$ concentration falls from 2 to $1 \mathrm{ng} / \mathrm{ml}$ and from 10 to $2 \mathrm{ng} / \mathrm{ml}$, respectively (Table III). These data, therefore, suggest that once the concentration of $\beta \mathrm{NGF}$ in the medium drops below $2 \mathrm{ng} / \mathrm{ml}$, suboptimal induction occurs.

Total DNA per dish was measured also. Log phase growth continued up until day 4 (Fig. 8), a time when up to $40 \%$ of the cells show neurites (Fig. 7, $B$ and $C$ ). This again suggests that the cessation of cell division is not a prerequisite for the initiation of neurite outgrowth. Analysis of DNA synthesis further supports this conclusion. The first significant decrease in DNA synthesis relative to control cultures receiving fresh medium plus serum every 2 days is observed on day 5 (Fig. 9). It is of interest that cells which receive no fresh serum and no $\beta$ NGF

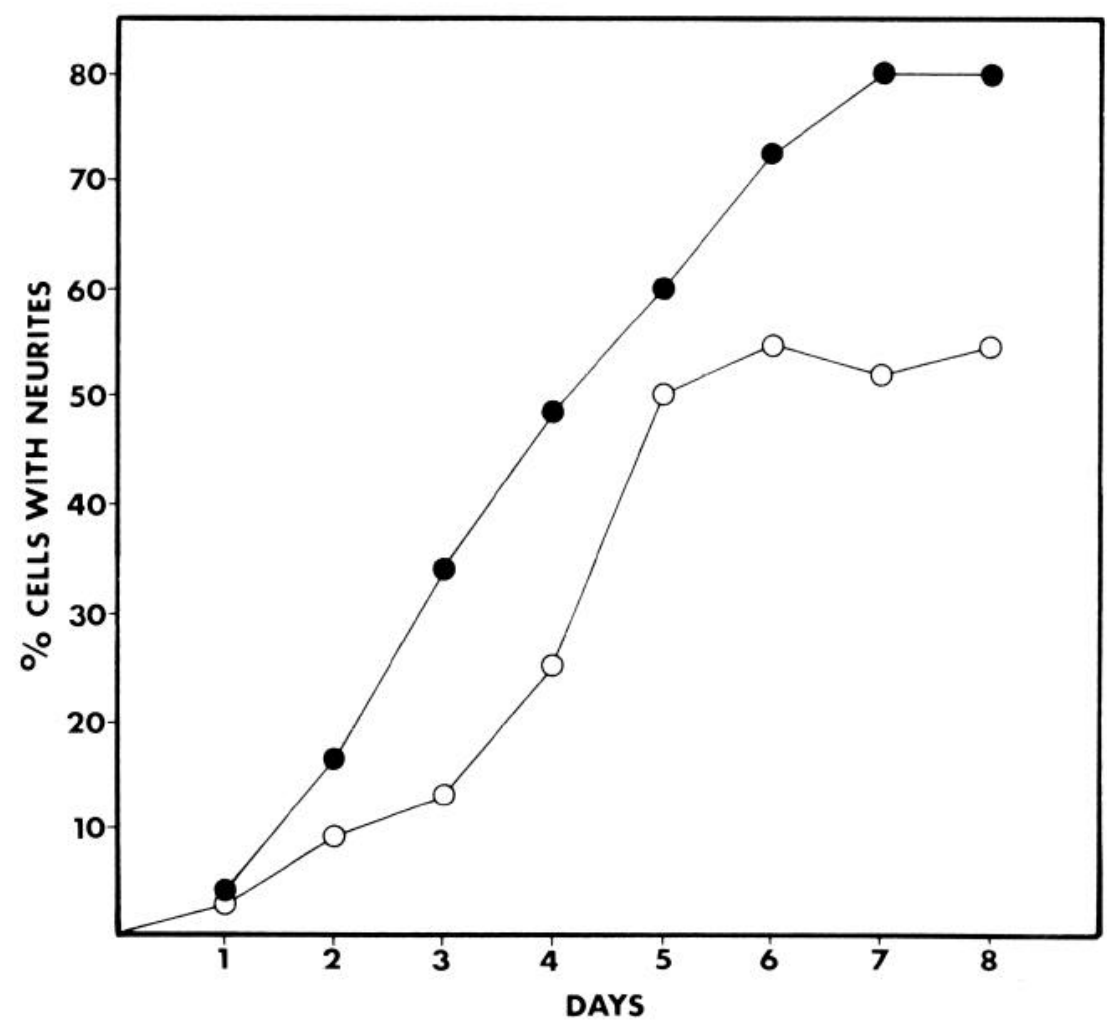

Figure 6. Effect of serum upon neurite outgrowth from PC12 cells. Subconfluent cells were replated and 2 days later, either fresh medium plus $150 \mathrm{ng} / \mathrm{ml}$ of $\beta \mathrm{NGF}(\mathrm{O})$ or fresh medium (minus serum) plus $1 \mathrm{mg} / \mathrm{ml}$ of BSA plus $100 \mathrm{ng} / \mathrm{ml}$ of $\beta \mathrm{NGF}(-\rightarrow)$ was added. Further additions were made every 2 days and the percentage of neurite-bearing cells was scored. 


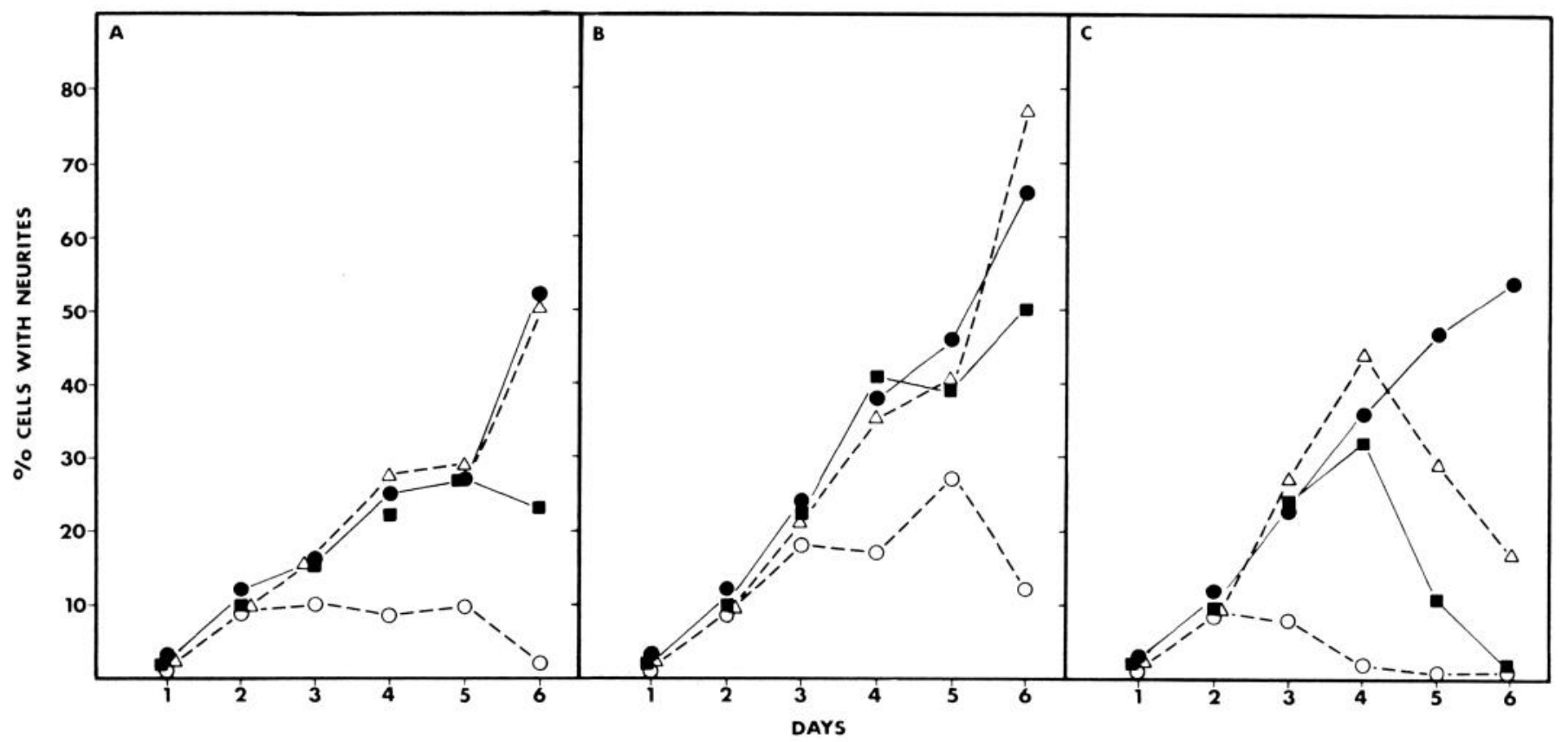

Figure 7. Effect of fresh serum addition upon neurite outgrowth from PC12 cells. Cells initially were treated exactly as described in Figure 1. At 2 and 4 days after the initial addition of fresh medium plus $\beta$ NGF, the following additions were made: $A$, fresh medium and $\beta$ NGF; $B$, fresh $\beta$ NGF only; $C$, no additions. The $\beta$ NGF concentrations were, in nanograms per ml, 5 $\left(\bigcirc_{--} \bigcirc\right), 25(\square), 50(\triangle--\triangle)$, and $150(-\square)$

TABLE II

$\beta N G F$ concentration during PC12 differentiation induced by fresh $\beta N G F$ addition only

Cells were treated exactly as described in Figure $7 B$.

\begin{tabular}{llrrr}
\hline Day & \multicolumn{4}{c}{ Concentration in Medium } \\
\hline & \multicolumn{4}{c}{$n g / m l$} \\
1 & 5 & 25 & 50 & 150 \\
$2^{a}$ & 3.9 & 21 & 43 & 124 \\
3 & 2.1 & 18 & 36 & 111 \\
$4^{a}$ & 2.9 & 30 & 56 & 214 \\
5 & 0.6 & 13 & 33 & 137 \\
6 & 1.1 & 22 & 41 & 225 \\
& 0 & 0 & 0 & 129 \\
\hline
\end{tabular}

${ }^{a}$ On days 2 and 4 , fresh $\beta$ NGF was added at concentrations of 5,25 , 50 , or $150 \mathrm{ng} / \mathrm{ml}$, but the medium was not replaced.

TABLE III

$\beta N G F$ concentration during PC12 differentiation induced by a single addition of $\beta N G F$

Cells were treated exactly as described in Figure $7 C$.

\begin{tabular}{llrrr}
\hline Day & \multicolumn{4}{c}{ Concentration in Medium } \\
\hline & \multicolumn{4}{c}{$n g / m l$} \\
$0^{\alpha}$ & 5 & 25 & 50 & 150 \\
1 & 3.9 & 21 & 43 & 124 \\
2 & 2.1 & 18 & 36 & 111 \\
3 & 1.5 & 11 & 27 & 98 \\
4 & 0.4 & 2 & 10 & 51 \\
5 & 0 & 1 & 2 & 21 \\
6 & 0 & 0 & 0 & 0 \\
\hline
\end{tabular}

${ }^{a}$ On day 0 , the cells received fresh medium and $\beta$ NGF at the indicated concentration. No further additions were made.

also decrease significantly in their DNA synthetic capacity at day 5 relative to serum supplemented controls (Fig. 9).

In contrast to DNA metabolism, the rate of increase in cellular RNA levels was elevated in the absence of fresh serum addition every 2 days and reached levels significantly higher than those attained in standard inductions (Fig. 10; cf., Fig. 3). The dose-response behavior was also altered (Fig. 10) and closely resembled that of neurite outgrowth (Fig. 7). The increases observed were also monophasic, thus suggesting that the previous biphasicity observed (Fig. 3) was a function of the addition of fresh serum every 2 days rather than an intrinsic property of the cellular response to $\beta \mathrm{NGF}$ per se.

Autoradiography. The above data suggest that morphologically differentiated cells still synthesize DNA. This was examined further by pulsing the cells with $\left[{ }^{3} \mathrm{H}\right]$ thymidine and locating the DNA-synthesizing cells using autoradiography. After 5 days exposure to $\beta \mathrm{NGF}$, a considerable number of cells, with neurites many cell body diameters in length, continued to incorporate thymidine into their nuclear DNA. An example of such a cell is shown in Figure 11. The intensity of grains within the nucleus of such cells was equal to the maximum intensity observed in nuclei of nonresponding cells. It is concluded, therefore, that cells which have differentiated morphologically can continue to synthesize DNA.

\section{Discussion}

Dose responsiveness of neurite induction. Previous work of Greene (1978) has demonstrated that optimal induction of neurite outgrowth from PC12 cells in serumfree medium occurs at 5 to $10 \mathrm{ng} / \mathrm{ml}$ of $\beta \mathrm{NGF}$. In contrast, regeneration of neurites from induced cells is optimal at 0.5 to $1 \mathrm{ng} / \mathrm{ml}$ of $\beta$ NGF (Greene, 1977). We have found that optimal neurite induction, measured as the fraction of cells displaying neurites, in the presence of medium containing serum requires 50 to $100 \mathrm{ng} / \mathrm{ml}$ of $\beta \mathrm{NGF}$, 


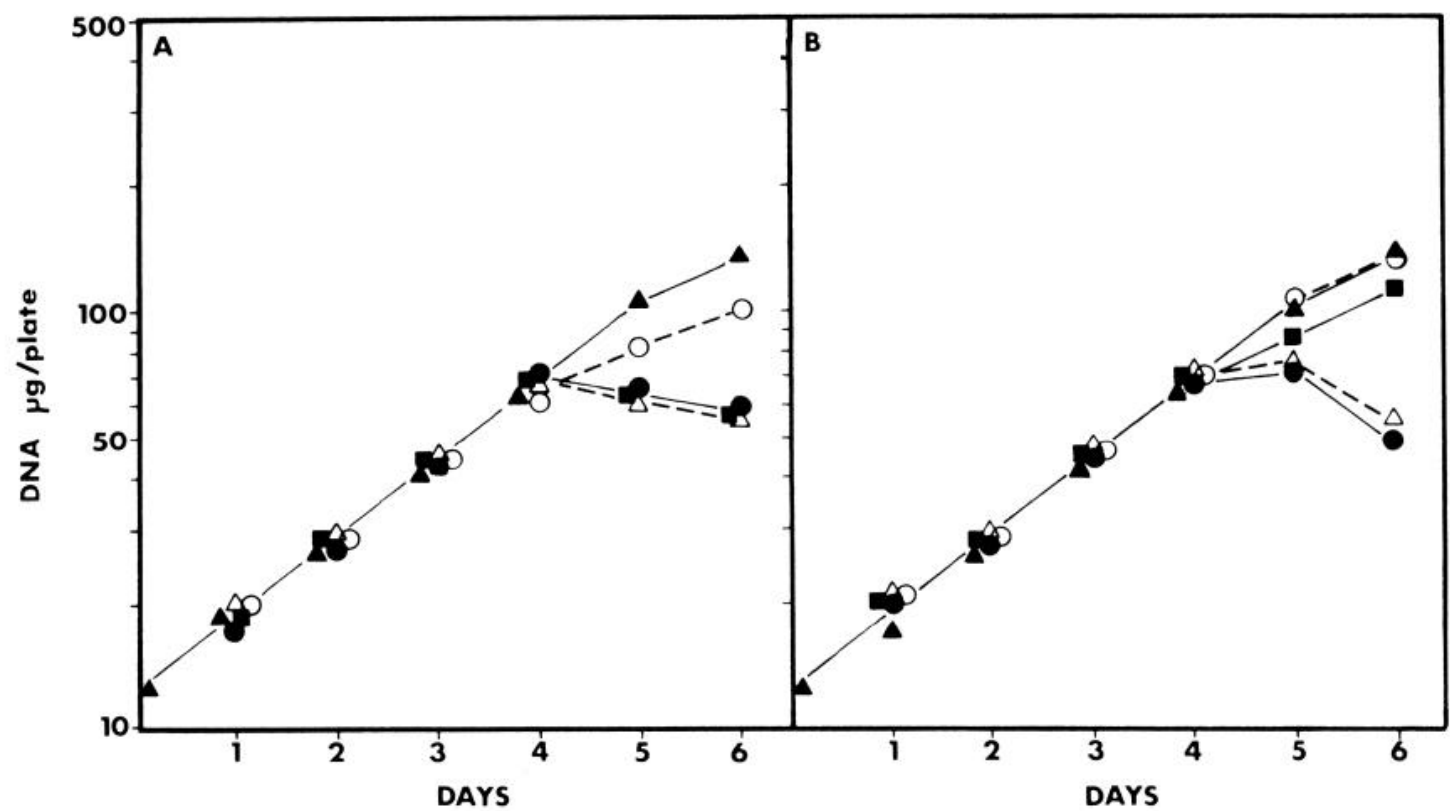

Figure 8. Effect of fresh serum addition upon cell division during PC12 differentiation. The cells were treated exactly as described in Figure 7. On days 2 and 4 , the cells received $(A)$ fresh $\beta$ NGF only or $(B)$ no additions. Cell division, measured as total DNA per plate, is shown for $\beta$ NGF concentrations of $0(\boldsymbol{\Delta}-\boldsymbol{\Delta}), 5\left(\bigcirc_{-} \bigcirc\right), 25(\square-\square), 50(\triangle--\triangle)$, and $150(-\bigcirc) \mathrm{ng} / \mathrm{ml}$

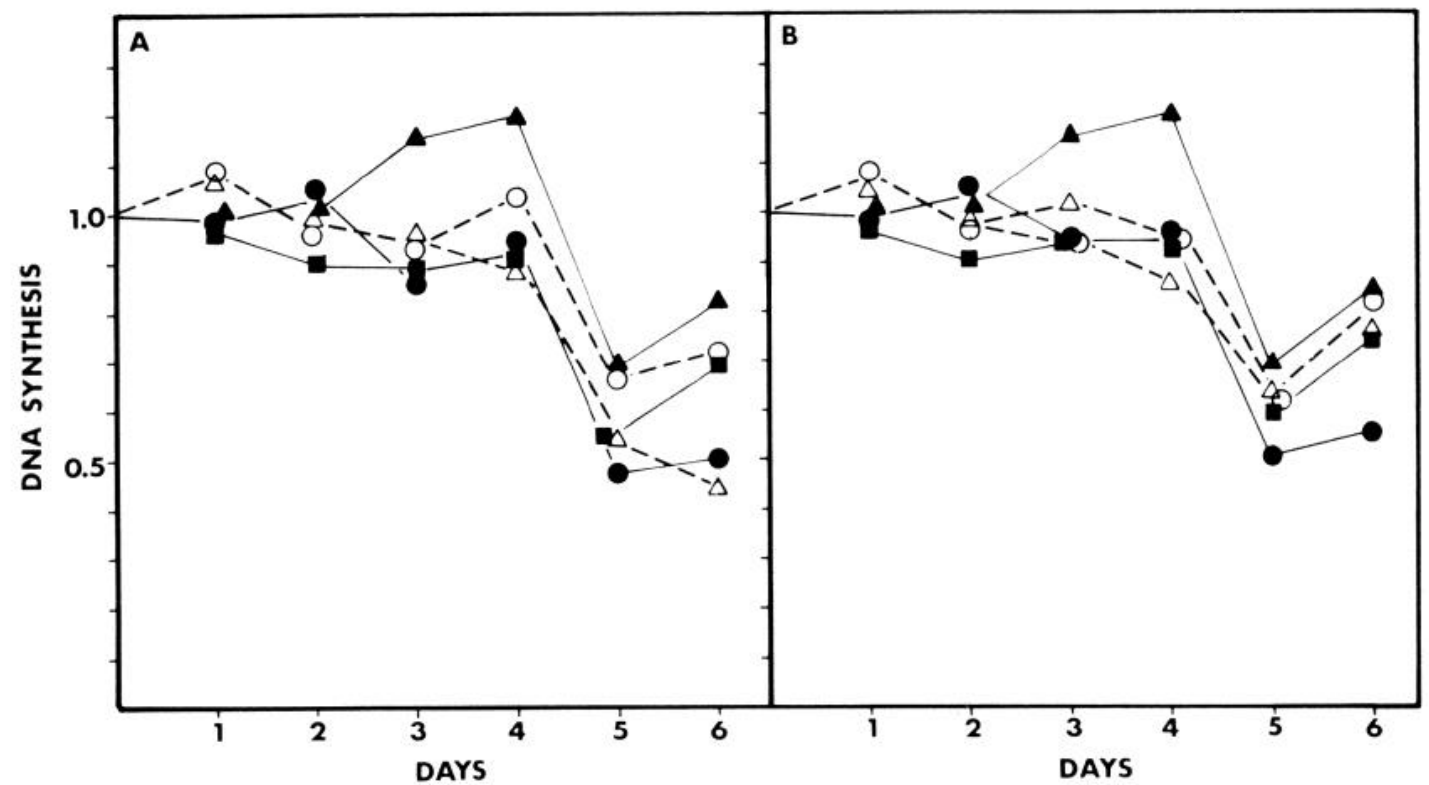

Figure 9. Effect of fresh serum addition upon DNA synthesis during PC12 differentiation. The cells were treated exactly as described in Figure 7. On days 2 and 4, the cells received $(A)$ fresh $\beta$ NGF only or $(B)$ no additions. DNA synthesis is presented as a ratio relative to control sister cultures which received fresh serum every 2 days. The $\beta$ NGF concentrations used were $0(\boldsymbol{\Delta}-\mathbf{\Delta}), 5\left(\bigcirc_{-}-\bigcirc^{-}\right), 25$ $(\square), 50(\triangle--\triangle)$, and $150(-0) \mathrm{ng} / \mathrm{ml}$.

while maximum neurite growth (as measured by the NGI) occurs at 100 to $250 \mathrm{ng} / \mathrm{ml}$ of $\beta$ NGF (Fig. $5 A$ ). Such results naturally raise the question of whether de novo induction requires a higher $\beta \mathrm{NGF}$ concentration than that of regeneration.

Examination of $\beta \mathrm{NGF}$ concentration as a function of the time of exposure to cells shows that considerable decreases occur within a day (Tables I to III). This decrease is, at least in part, a function of cell density and primarily involves lysosomal degradation of $\beta$ NGF (P. Layer and E. M. Shooter, manuscript in preparation). It is clear, therefore, that attempts to measure the true optimal concentration of $\beta \mathrm{NGF}$ necessary to elicit biological effects must take this phenomenon into consideration. In the case of de novo neurite induction in the presence of serum, we have found that optimal induction is observed when the $\beta$ NGF level remains above $2 \mathrm{ng} / \mathrm{ml}$ (Tables II and III). This is very close to the level required 


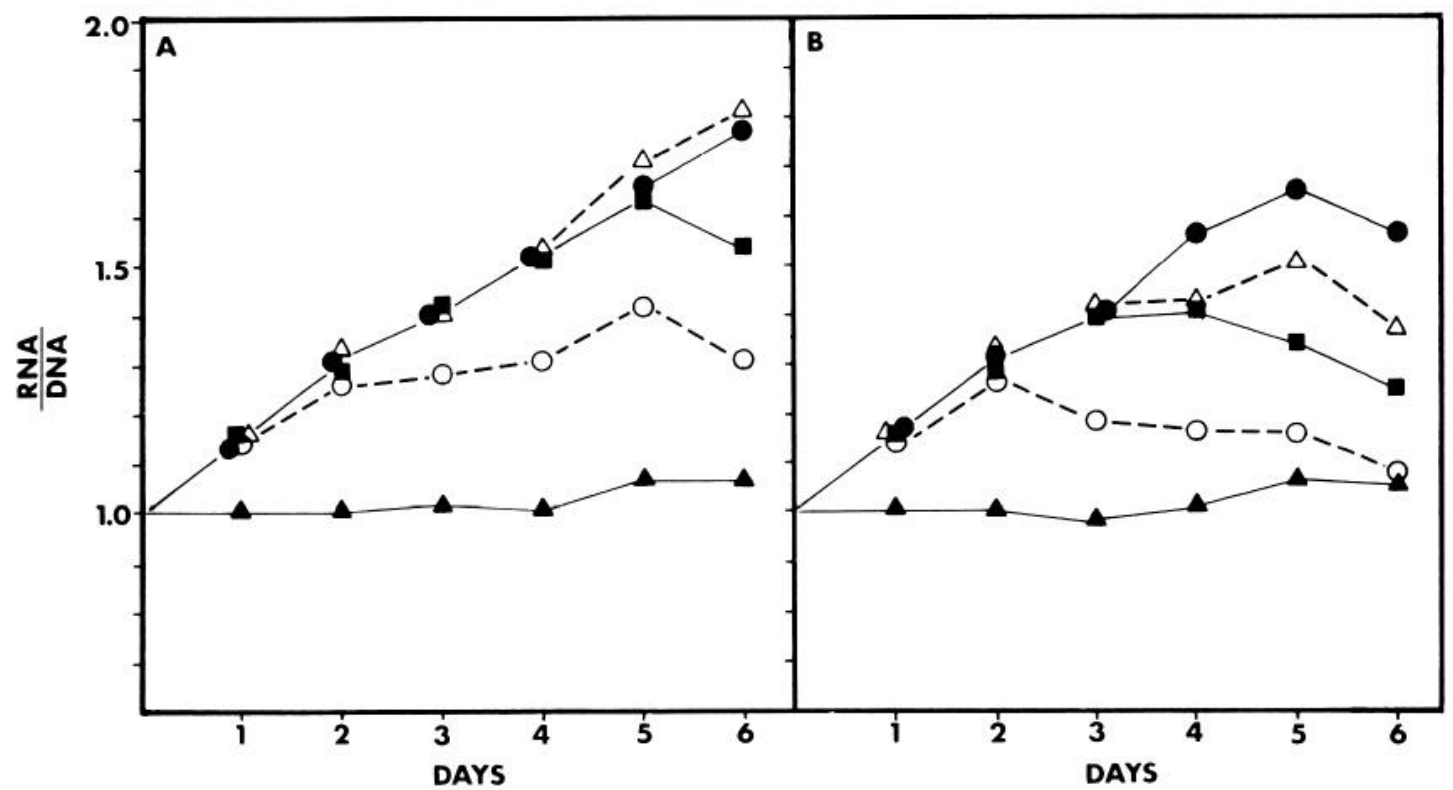

Figure 10. Effect of fresh serum addition upon the cellular RNA concentration during PC12 differentiation. The cells were treated exactly as described in Figure 7 . On days 2 and 4 , the cells received $(A)$ fresh $\beta$ NGF only or $(B)$ no additions. The cellular RNA concentration, measured as RNA/DNA, is presented as a ratio relative to control sister cultures which received fresh serum every 2 days. The $\beta$ NGF concentrations used were $0(\boldsymbol{\Delta}-\boldsymbol{\Delta}), 5\left(\bigcirc_{-}-\mathrm{O}\right), 25\left(\square \square-\square^{-}, 50(\Delta---\Delta)\right.$, and $150(-) \mathrm{ng} / \mathrm{ml}$.

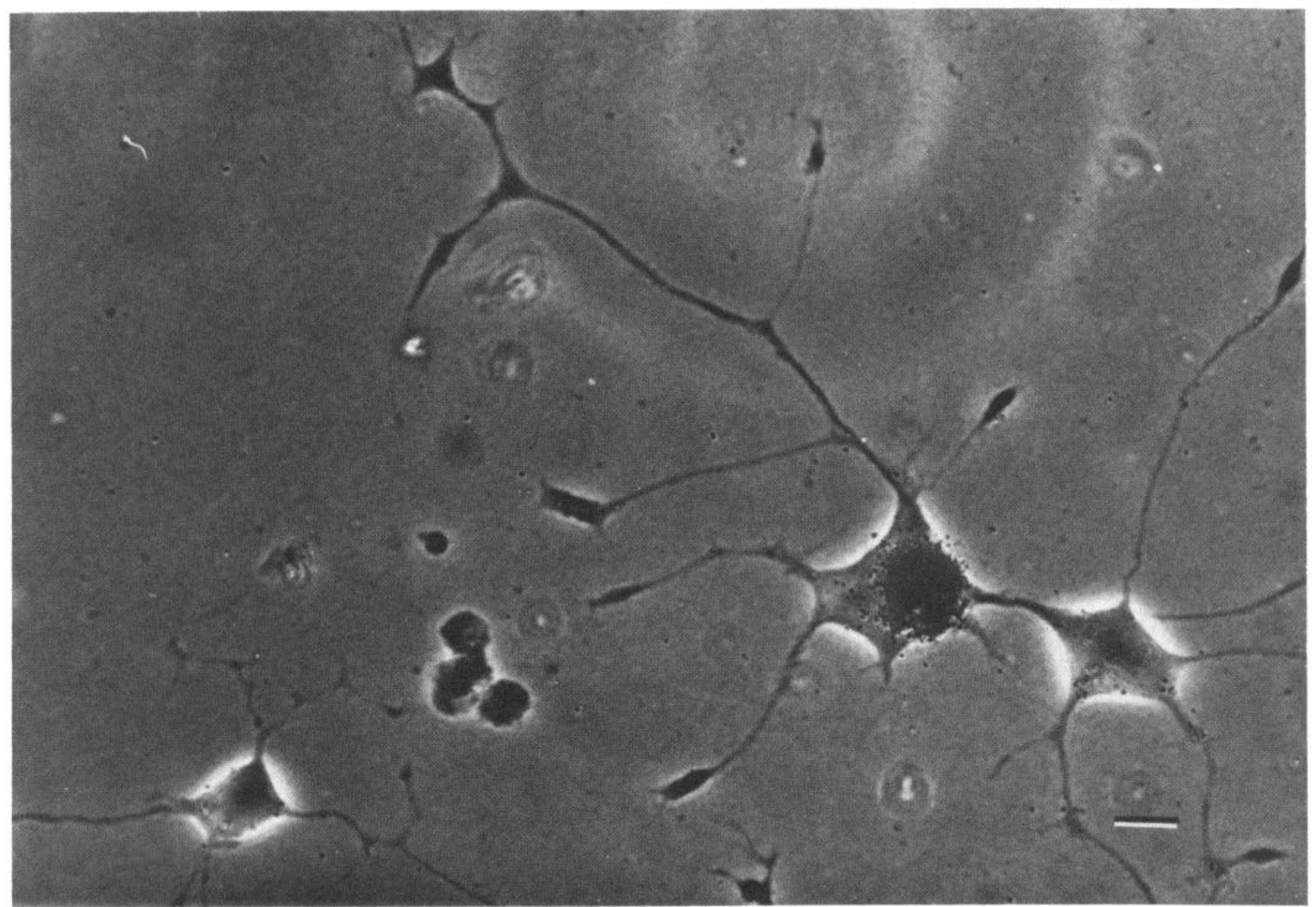

Figure 11. Synthesis of DNA within morphologically differentiated PC12 cells. Cells were treated with $50 \mathrm{ng} / \mathrm{ml}$ of $\beta$ NGF for 5 days prior to a 2 -hr exposure to $\left[{ }^{3} \mathrm{H}\right]$ thymidine. Autoradiography was performed as described under "Materials and Methods." Over 1000 cells were examined and approximately $8 \%$ of the morphologically differentiated cells displayed intense labeling within their nuclei. A typical example is shown. The bar represents $10 \mu \mathrm{m}$. 
for optimal neurite regeneration (Greene, 1977). It therefore appears from these similar dose requirements for the two $\beta$ NGF-mediated events that similar plasma membrane receptor occupancy is needed for both de novo neurite induction and neurite regeneration.

Role of cell division. It has been suggested that $\mathrm{PC} 12$ cells begin to put out neurite processes after cell division has stopped (Greene and Tischler, 1976; Dichter et al., 1977). This conclusion was based upon cell growth curves similar to those shown in Figure $2 A$ and the onset time of neurite growth. We have found that, after two cell doublings (4 days), the cell number on the dish (measured as total DNA) no longer increases (Fig. 2, $A$ and $B$ ). However, analysis of the level of DNA synthesis reveals that there is only a gradual decrease in synthesis, and probably cell division, after day 4 rather than a total cessation (Figs, $2 B$ and 9). This apparent contradiction is explained, at least in part, by the loss of cells through death and lifting off the dish into the medium. This may balance the continued, albeit reduced, cell division. Thus, measurements of the cell number or DNA content per dish are potentially misleading.

Indirect evidence in a number of experiments suggested that neurite outgrowth occurs independent of the cessation of cell division. In particular, $(i)$ there is no decrease in cell division preceding the initial appearance of neurites (Figs. 1, 2, and 7 to 9); (ii) a dose-responsive decrease in DNA synthesis is seen only after 6 days, by which time, maximal neurite induction has been attained (Figs. 1 and 2); (iii) increasing the rate of neurite induction does not alter the rate of decrease in DNA synthesis and cell division (Figs. 7 to 9). This conclusion is confirmed by the autoradiographic studies (Fig. 11).

Although morphologically differentiated cells still can synthesize DNA, three questions remain. Firstly, does total inhibition of DNA synthesis potentiate $\beta$ NGF-induced PC12 differentiation? We have found that addition of $1 \mu \mathrm{M}$ cytosine arabinoside, which reduces DNA synthesis by over $99 \%$, plus $\beta \mathrm{NGF}$ yields no increase in the rate of neurite induction over that of $\beta \mathrm{NGF}$ alone $(\mathrm{G}$. E. Landreth, P. W. Gunning, and E. M. Shooter, unpublished observation). Furthermore, incubation with cytosine arabinoside alone produces no neurite outgrowth. Secondly, what is the significance of the final cessation of cell division? Recent studies of Rothman et al. (1978) have suggested that most of the differentiated properties of chick sympathetic neurons are acquired prior to the cessation of cell division. These authors did not assess, however, the role of cell division with relation to process outgrowth from these cells. The results obtained here suggest that the cessation of PC12 cell division is one of the final events in their differentiation. Whether there is any relationship between the length of neurites and the cessation of cell division or DNA synthesis is currently under investigation. It must be noted, of course, that extrapolation from this tumor cell system to the normal differentiation of sympathetic neurons is, at best, tenuous. Finally, it is not clear whether this continued DNA synthesis truly reflects continued cell division. More recently, we have demonstrated that at least $70 \%$ of the morphologically differentiating cells, after 12 days exposure to $\beta \mathrm{NGF}$, continue to synthesize DNA. Using time- lapse cinematography, it has been shown further that a significant number (over 10\%) of these differentiated cells have remained in the cell cycle and undergo cell division. (M. Ignatius, C. Chandler, P. W. Gunning, G. E. Landreth, and E. M. Shooter, manuscript in preparation).

Role of increasing RNA levels. That the increase observed in the cellular level of RNA is involved in the morphological differentiation of these cells is supported by the following: (i) The increase in cellular RNA precedes neurite induction (Figs. 1 and 3); (ii) half-maximal stimulation of the RNA level after $24 \mathrm{hr}$ exposure to $\beta \mathrm{NGF}$ requires less than $0.25 \mathrm{ng} / \mathrm{ml}$ of the hormone (Fig. 4); (iii) the increase in RNA shows similar temporal doseresponse variation to that of neurite outgrowth (Figs. 1 and 3$)$; (iv) increasing the rate of neurite induction is paralleled with an increase in the rate of RNA elevation (Figs. 7 and 10).

Detailed dose-response analysis indicates that this increase in RNA is related to the size and number of neurites per cell rather than the intrinsic capacity to initiate neurite outgrowth (Fig. $5 B$ ). The increase affects equally both rRNA and tRNA levels. This would be expected to raise the protein synthesis capacity of the cells. The finding that the cellular protein level is tied closely to the RNA content (Figs. 3,4 , and $5, B$ and $C$ ) suggests that the rise in RNA produces and maintains the increase of protein levels. Such a rise in the cellular protein content, indeed, would be expected to promote the extent of neurite outgrowth.

This conclusion is supported by recent experiments utilizing dibutyryl cyclic AMP ( $\left.\mathrm{Bt}_{2} \mathrm{cAMP}\right)$. It has been found that the initiation of neurite outgrowth in the presence of $B t_{2} c A M P$ plus $\beta N G F$ is independent of RNA and protein synthesis (P. W. Gunning, G. E. Landreth, M. A. Bothwell, and E. M. Shooter, manuscript in preparation). This shows that a general increase in cellular RNA and protein is not required for the neurite initiation event.

NGF has been shown previously, at a morphological level, to stimulate nuclear activity in responsive neurons. In particular, administration of NGF to mice increases the size of nucleoli within sympathetic neurons (Angeletti et al., 1971). A similar response also has been noted in the nucleoli of newt retinal ganglion cells (Turner and Delaney, 1979). In contrast, administration of NGF antiserum leads to a degeneration of the nucleolus within sympathetic neurons and is one of the earliest cytotoxic effects observed (Levi-Montalcini et al,, 1969). Guroff and co-workers also have detected a rise in RNA polymerase activity within nuclei isolated from rat sympathetic ganglia following administration of NGF (Huff et al., 1978). These data suggest that nucleolar function may be under the direct control of $\beta \mathrm{NGF}$ in responsive neurons. Currently, we are investigating the synthesis and processing of pre-rRNA within the $\mathrm{PCl} 2$ cell nucleolus.

\section{References}

Angeletti, P. V., R. Levi-Montalcini, and F. Caramia (1971) Ultrastructural changes in sympathetic neurons of newborn and adult mice treated with nerve growth factor. J. Ultrastruct. Res. 36: 24-36.

Burstein, D. E., and L. A. Greene (1978) Evidence for RNA 
synthesis-dependent and -independent pathways in stimulation of neurite outgrowth by nerve growth factor. Proc. Natl. Acad. Sci. U. S. A. 75: 6059-6063.

Dichter, M. A., A. S. Tischler, and L. A. Greene (1977) Nerve growth factor-induced increase in electrical excitability and acetylcholine sensitivity of a rat pheochromocytoma cell line. Nature 268: 501-504.

Garrels, J. E., and D. Schubert (1979) Modulation of protein synthesis by nerve growth factor. J. Biol. Chem. 254: 79787985.

Greene, L. A. (1977) A convenient and sensitive quantitative bioassay for nerve growth factor activity employing a clonal pheochromocytoma cell line. Brain Res. 133: 350-353.

Greene, L. A. (1978) Nerve growth factor prevents the death and stimulates the neuronal differentiation of clonal PC12 pheochromocytoma cells in serum-free medium. J. Cell Biol. 78: 747-755.

Greene, L. A., and A. S. Tischler (1976) Establishment of a noradrenergic clonal line of rat adrenal pheochromocytoma cells which respond to nerve growth factor. Proc. Natl. Acad. Sci. U. S. A. 73: 2424-2428.

Gunning, P. W., L. Austin, and P. L. Jeffrey (1979) The turnover and subcellular localization of the chick forebrain small nuclear RNAs. J. Neurochem. 32: 1725-1736.

Hatanaka, H., V. Otten, and H. Thoenen (1978) Nerve growth factor-mediated selective induction of ornithine decarboxylase in rat pheochromocytoma: A cyclic AMP-independent process. FEBS Lett. 92: 313-316.

Huff, K., J. Lakshmanan, and G. Guroff (1978) RNA polymerase activity in the superior cervical ganglion of the neonatal rat: The effect of nerve growth factor. J. Neurochem. 31: 599606.

Kopriwa, B. M., and L. P. Leblond (1962) Improvement in the coating technique of radioautography. J. Histochem. Cytochem. 10: 269-284.

Letourneau, P. (1975) Possible roles for cell to substratum adhesion in neuronal morphogenesis. Dev. Biol. 44: 77-91.

Levi-Montalcini, R., F. Caramia, and P. U. Angeletti (1969) Alterations in the fine structure of nucleoli in sympathetic neurons following NGF-antiserum treatment. Brain Res. 12: $54-73$.
Lowry, O. H., N. J. Rosebrough, A. L. Farr, and R. J. Randall (1951) Protein measurement with the Folin phenol reagent. J. Biol. Chem. 193: 265-275.

McGuire, J. C., and L. A. Greene (1979) Rapid stimulation by nerve growth factor of amino acid uptake by clonal PC12 pheochromocytoma cells. J. Biol. Chem. 254: 3362-3367.

McGuire, J. C., L. A. Greene, and A. V. Furano (1978) NGF stimulates incorporation of fucose or glucosamine into an external glycoprotein in cultured rat $\mathrm{PC} 12$ pheochromocytoma cells. Cell 15: 357-365.

Mizel, S. B., and J. R. Bamburg (1976) Studies on the action of nerve growth factor. I. Characterization of a simplified in vitro culture system for dorsal root and sympathetic ganglia. Dev. Biol. 49: 11-19.

Rothman, R. P., M. D. Gershon, and H. Holtzer (1978) The relationship of cell division to the acquisition of adrenergic characteristics by developing sympathetic ganglion cell precursors. Dev. Biol. 65: 322-341.

Schubert, D., S. Heinemann, and Y. Kidokoro (1977) Cholinergic metabolism and synapse formation by a rat nerve cell line. Proc. Natl. Acad. Sci. U. S. A. 74: 2579-2583.

Smith, A. P., S. Varon, and E. M. Shooter (1968) Multiple forms of the nerve growth factor protein and its subunits. Biochemistry 1: 3259-3268.

Sutter, A., R. J. Riopelle, R. M. Harris-Warrick, and E. M. Shooter (1979) Nerve growth factor receptors. Characterization of two distinct classes of binding sites on chick embryo sensory ganglia cells. J. Biol. Chem. 254: 5972-5982.

Tsanev, R., and G. G. Markov (1960) Substances interfering with spectrophotonetric estimation of nucleic acids and their elimination by the two-wavelength method. Biochim. Biophys. Acta 42: 442-452.

Turner, J. E., and R. K. Delaney (1979) Retinal ganglion cell response to axotomy and nerve growth factor in the regeneration visual system of the newt (Notophthalmus viridescens): An ultrastructural morphometric analysis. Brain Res. 171: 197-212.

Yankner, B. A., and E. M. Shooter (1979) Nerve growth factor in the nucleus: Interaction with receptors on the nuclear membrane. Proc. Natl. Acad. Sci. U. S. A. 76: 1269-1273. 